\title{
TITLE: COST-EFFECTIVE METHOD FOR PRODUCING SELF SUPPORTED PALLADIUM ALLOY MEMBRANES FOR USE IN EFFICIENT PRODUCTION OF COAL DERIVED HYDROGEN
}

\section{QUARTERLY TECHNICAL PROGRESS REPORT}

\begin{tabular}{|c|c|}
\hline REPORTING PERIOD START DATE: & 9/09/03 (PROGRAM START) \\
\hline REPORTING PERIOD END DATE: & 07/30/04 \\
\hline PRINCIPLE AUTHOR(S): & $\begin{array}{l}\text { B. LANNING, J. ARPS } \\
210522-2934 \text { (Phone) } \\
210522-6220 \text { (Fax) }\end{array}$ \\
\hline DATE REPORT WAS ISSUED: & JULY 2004 \\
\hline DOE AWARD NUMBER: & DE-FC26-03NT41849 \\
\hline SUBMITTING ORGANIZATION: & $\begin{array}{l}\text { SOUTHWEST RESEARCH INSTITUTE } \\
6220 \text { CULEBRA ROAD }(78238-5166) \\
\text { P.O. BOX } 28510 \quad(78228-0510) \\
\text { SAN ANTONIO, TEXAS }\end{array}$ \\
\hline OTHER TEAM MEMBERS: & $\begin{array}{l}\text { COLORADO SCHOOL OF MINES } \\
\text { IDATECH }\end{array}$ \\
\hline SUBMIT TO: & $\begin{array}{l}\text { NETL AAD DOCUMENT CONTROL } \\
\text { BLDG. } 921 \text { U.S. DEPARTMENT OF ENERGY } \\
\text { NATIONAL ENERGY TECHNOLOGY LABORATORY } \\
\text { P.O. BOX } 10940 \\
\text { PITTSBURGH, PA } 15236-0940\end{array}$ \\
\hline
\end{tabular}

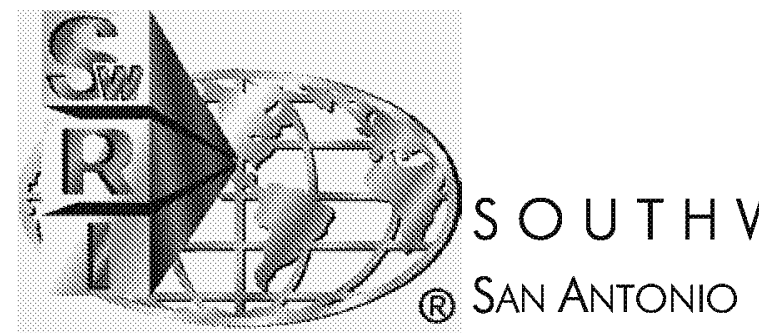




\title{
TITLE: COST-EFFECTIVE METHOD FOR PRODUCING SELF SUPPORTED PALLADIUM ALLOY MEMBRANES FOR USE IN EFFICIENT PRODUCTION OF COAL DERIVED HYDROGEN
}

\section{QUARTERLY TECHNICAL PROGRESS REPORT}

\author{
REPORTING PERIOD START DATE: 9/09/03 (PROGRAM START) \\ REPORTING PERIOD END DATE: $\quad$ 07/30/04 \\ PRINCIPLE AUTHOR(S): $\quad$ B. LANNING, J. ARPS \\ 210 522-2934 (Phone) \\ $210522-6220$ (Fax) \\ DATE REPORT WAS ISSUED: JULY 2004 \\ DOE AWARD NUMBER: DE-FC26-03NT41849 \\ SUBMITTING ORGANIZATION: SOUTHWEST RESEARCH INSTITUTE \\ 6220 CULEBRA ROAD (78238-5166) \\ P.O. BOX 28510 (78228-0510) \\ SAN ANTONIO, TEXAS \\ OTHER TEAM MEMBERS: $\quad$ COLORADO SCHOOL OF MINES \\ IDATECH \\ SUBMIT TO: \\ NETL AAD DOCUMENT CONTROL \\ BLDG. 921 U.S. DEPARTMENT OF ENERGY \\ NATIONAL ENERGY TECHNOLOGY LABORATORY \\ P.O. BOX 10940 \\ PITTSBURGH, PA 15236-0940
}

APPROVED:

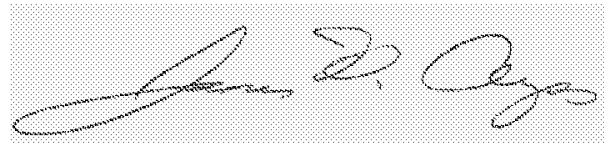

James H. Arps, Manager

Surface Engineering Section 


\section{DISCLAIMER}

"This report was prepared as an account of work sponsored by an agency of the United States Government. Neither the United States Government nor any agency thereof, nor any of their employees, makes any warranty, express or implied, or assumes any legal liability or responsibility for the accuracy, completeness, or usefulness or any information, apparatus, product, or process disclose, or represents that its use would not infringe privately owned rights. Reference herein to any specific commercial product, process, or service by trade name, trademark, manufacturer, or otherwise does not necessarily constitute or imply its endorsement, recommendation, or favoring by the United States Government or any agency thereof. The views and opinions of authors expressed herein do not necessarily state or reflect those of the United States Government or any agency thereof." 


\begin{abstract}
In continuation of efforts from last quarter, processing parameters, used in the formation of $\mathrm{Pd}-\mathrm{Cu}$ alloy films, were being optimized in a drum (web) coater system with the goal of producing large-area, contiguous, pinhole-free films for $\mathrm{H}_{2}$ separation membranes. Since the (pre-treatment) functionality of the surface of the plastic backing material is sub-optimal, we tended to produce films in the drum coater that were either not contiguous (disseminates upon release from the polymer backing material) or contain pinholes. Alternative approaches, such as direct deposition onto thermally oxidized silicon wafers, have been attempted to yield pinhole-free films; i.e., formation of a poorly adherent $\mathrm{Pd}-\mathrm{Cu}$ film on silicon will then directly release from the silicon substrate.

Permeation characteristics of a $25 \mu$ m-thick, $\mathrm{Pd}_{60} \mathrm{Cu}_{40}$ alloy foil were conducted. After pre-treating the sample to stabilize the FCC $\beta$-phase, the hydrogen permeability was determined to be $5.4 \times 10^{-5} \mathrm{~cm}^{3} \mathrm{cmcm}^{-2} \mathrm{~s}^{-1} \mathrm{cmHg}^{-1 / 2}$ (In good agreement with the Juda Patent). Thin, 1 - $3 \mu \mathrm{m}$-thick $\mathrm{Pd}-\mathrm{Cu}$ alloy films have been prepared on PS films and samples will be prepared and tested in the next quarter.
\end{abstract}




\section{Table of Contents}

DISCLAIMER................................................................................................................... iii

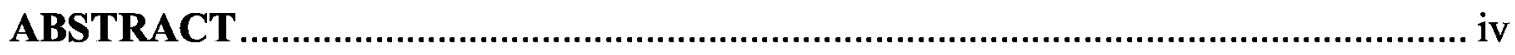

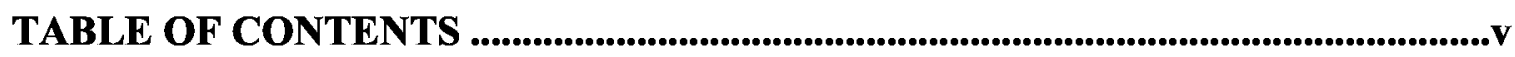

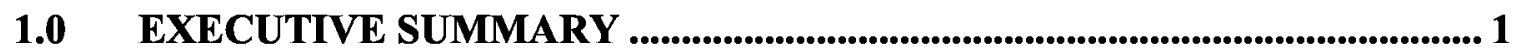

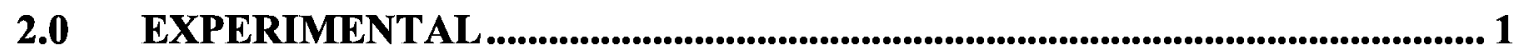

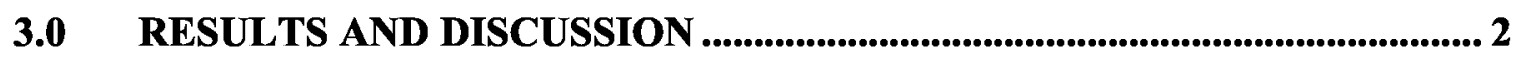

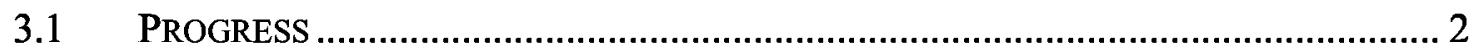

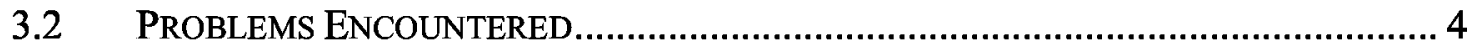

3.3 PLANS FOR NEXT REPORTING PERIOD ................................................... 5

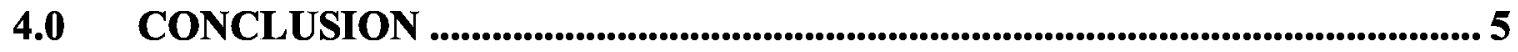

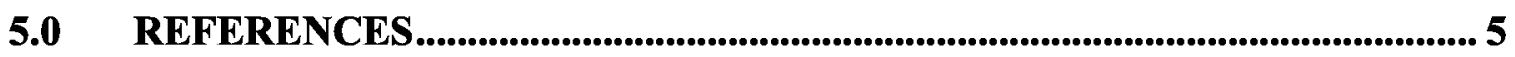




\title{
1.0 EXECUTIVE SUMMARY
}

\author{
Refer to abstract.
}

\subsection{EXPERIMENTAL}

$P d-C u$ alloy Vacuum Deposition - As described in the previous quarterly report, $\mathrm{Pd}-\mathrm{Cu}$ alloy films were deposited onto both PVA (Solublon) and polystryrene (PS) backing materials using magnetron sputtering and e-beam evaporation. Both magnetron and e-beam Pd-Cu alloy films were deposited onto plastic backing materials in a drum (web) coating configuration. The surface of the plastic was pre-treated in an argon ion beam in order to displace surface-adsorbed moisture and increase surface energy (for improved film wettability).

$\mathrm{Pd}-\mathrm{Cu}$ alloy films were also magnetron sputtered onto silicon substrates in the drum coater system. Samples were affixed to the drum and held stationary during the deposition process.

$\boldsymbol{H}_{2}$ Testing - To enable permeation testing of the membranes at high temperatures (up to $450^{\circ} \mathrm{C}$ ), a high temperature, pure gas transport apparatus has been assembled and feasibility of the apparatus was demonstrated by pre-annealing and testing a $25 \mu \mathrm{m}$-thick, commercially available, $\mathrm{Pd}_{60} \mathrm{Cu}_{40}$ alloy foil from Wilkinson Company of Post Falls, Idaho. Commercially available Grafoil valve packing material (Figure 1) was used to seal the $25 \mathrm{~mm}$ Millipore membrane cell, allowing a $650^{\circ} \mathrm{C}$ upper use temperature in oxygen-free environments.

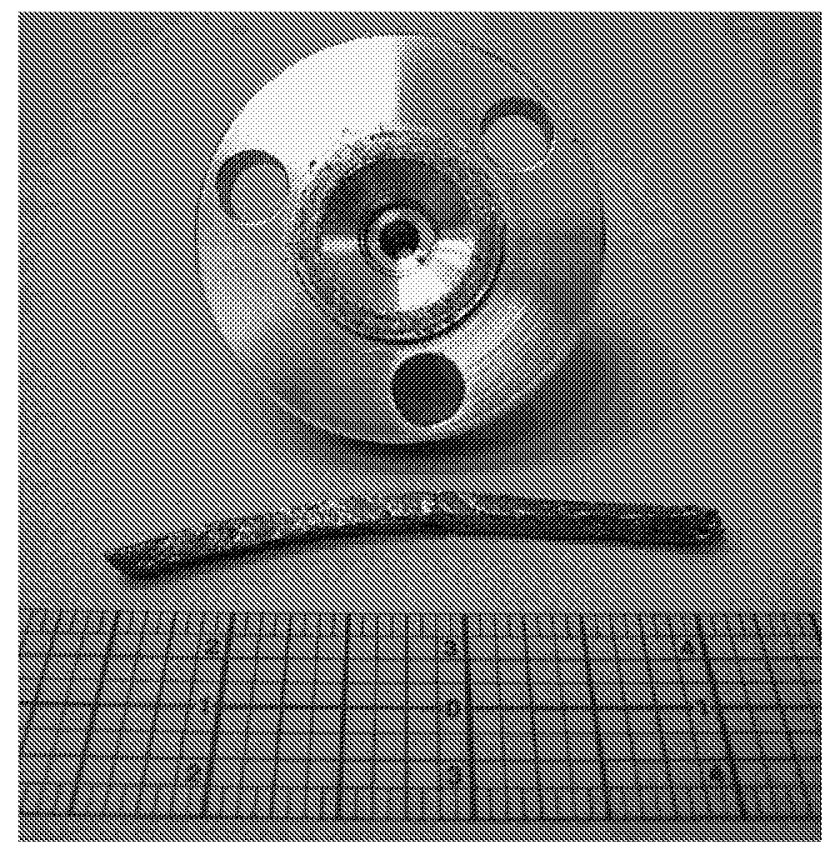

Figure 1. $25 \mathrm{~mm}$ Millipore membrane cell with high temperature Grafoil valve packing material used in place of a polymer o-ring. Maximum use temperature of Grafoil material is $650^{\circ} \mathrm{C}$. 


\subsection{RESULTS AND DISCUSSION}

\subsection{Progress}

\subsubsection{Pd-Cu Alloy Deposition}

Building upon the preliminary results from the previous quarter, we conducted a series of tests using both magnetron sputtering and e-beam evaporation in the drum web coating system. In the case of magnetron sputtering from a $60 \% \mathrm{Pd}, 40 \% \mathrm{Cu}$ alloy target, films were produced on $25 \mathrm{~cm}$-wide PS and PVA material up to $\sim 2$ meter lengths. Although adherent films were produced with very low strain, the films did not remain intact upon release from the backing material; i.e., both films disseminated into small fragments with the $\mathrm{Pd}-\mathrm{Cu}$ alloy films on PS forming much larger fragments than those on PVA. The fragmentation can be explained by the non-optimized plasma treatment of the plastic surface (functionalization) to increase the surface energy. Also, it is believed the observed differences between the PVA and PS is due to the amount of adsorbed water; i.e., the higher level on PVA creating a more non-wettable surface. Optimization of the surface pre-treatment is in progress and results will be reported next quarter.

In the case of the e-beam evaporated films we reported last quarter, there was the difficulty of forming contiguous alloy layers at deposition rates greater than $5 \mathrm{~nm} / \mathrm{sec}$. We therefore, produced pure $\mathrm{Cu}$ and pure $\mathrm{Pd}$ single layer films in the web coater to demonstrate formation of $25 \mathrm{~cm}$-width, contiguous films. We have subsequently demonstrated the formation of multi-layer (alternating $\mathrm{Cu} / \mathrm{Pd}$ ) films that are contiguous and are in the process of evaluating $25 \mathrm{~cm}$-side, co-evaporated films; results to be presented next quarter.

All Pd-Cu alloy films on plastic to date, have contained some level of defects (pinholes) and until we optimize the pre-treatment conditions to properly functionalize the surface, we will continue to promote formation of these types of defects. Testing will continue next quarter to optimize surface energy (through functionalization) and eliminate surface-adsorbed water.

\subsubsection{Pd-Cu Alloy Deposition on Silicon}

As an alternative, interim method to address the issue of defects in the Pd-Cu alloy membrane films, films are being deposited onto smooth, thermally oxidized silicon wafers. Particulate and other contaminants can be more readily controlled (i.e., minimized) on a silicon surface in comparison to plastic, and is considerably smoother than plastic. In preliminary experiments using magnetron sputtering, we were able to produce relatively pinhole-free coatings that would easily release from the silicon substrate (poor adherence). Additional tests are in progress to yield larger area samples with no pinholes (i.e., incorporation of clean-room preparation procedures). 


\subsection{3 $\mathrm{H}_{2}$ Permeation Testing}

Permeation characteristics of a $25 \mu \mathrm{m}$-thick, $\mathrm{Pd}_{60} \mathrm{Cu}_{40}$ alloy foil were conducted. Prior to measuring the permeation characteristics, the foil was annealed under hydrogen for 5 days at $450^{\circ} \mathrm{C}$ to facilitate formation of the higher permeability, FCC $\beta$-phase, followed by a 1-hour treatment in air at the same temperature. XRD analysis, before and after annealing, clearly indicated that the foil had changed from the a-phase to the b-phase. Pure $\mathrm{H}_{2}$ permeation tests were carried out with a trans-membrane pressure between 15 and $50 \mathrm{psi}$, all at $400^{\circ} \mathrm{C}$. Figure 2 shows a plot of pure gas permeability versus differential pressure raised to the one-half power. The $\mathrm{H}_{2}$ permeability was determined to be $5.4 \times 10^{-5} \mathrm{~cm}^{3} \mathrm{cmcm}^{-2} \mathrm{~s}^{-1} \mathrm{cmHg}^{-1 / 2}$. This is in good agreement with the Juda Patent (USP 6,238,645). See Figure 3.

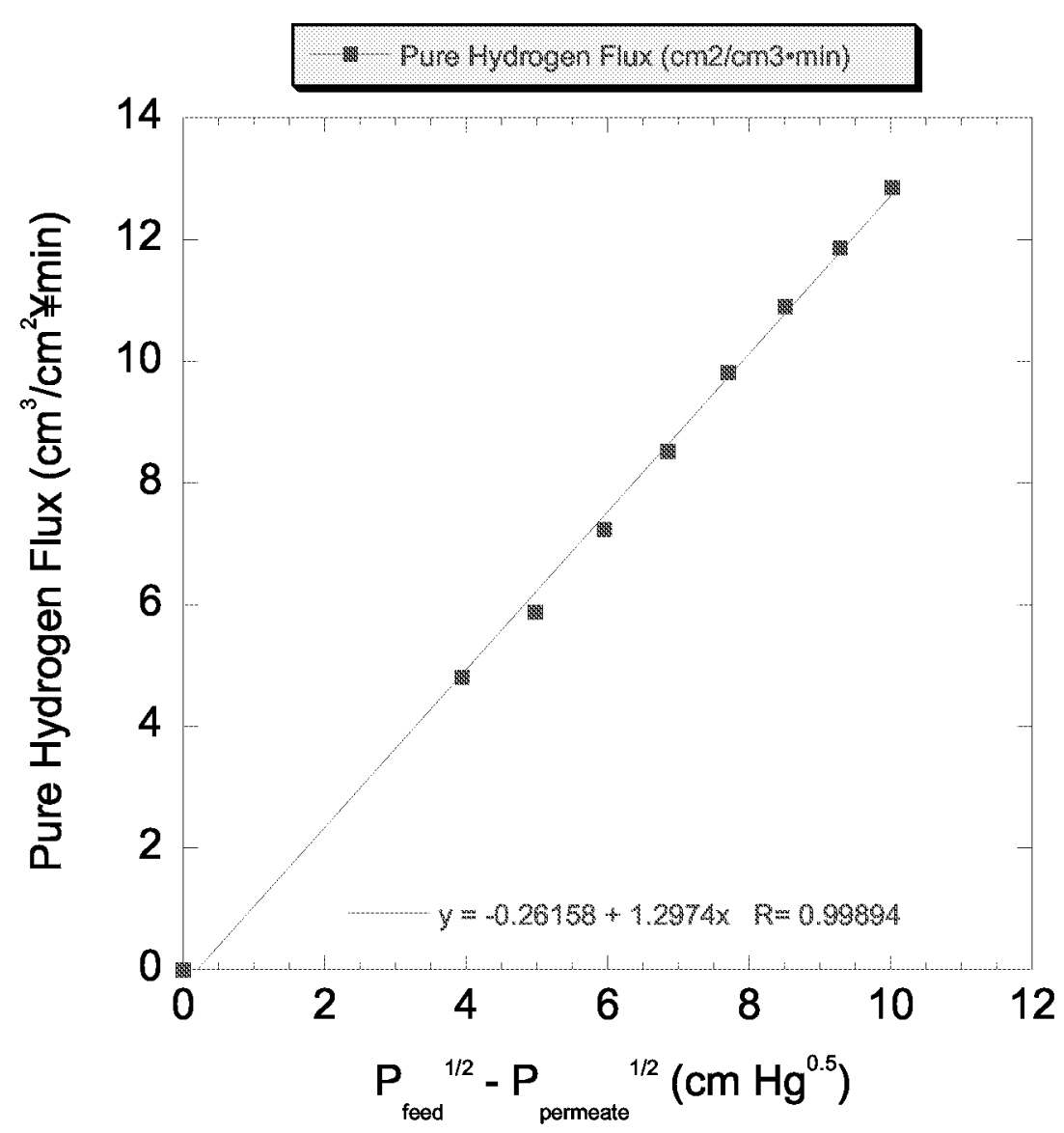

Figure 2. $\mathrm{H}_{2}$ flux versus differential pressure of $25 \mu \mathrm{m}$ thick $\mathrm{Pd}_{60} \mathrm{Cu}_{40}$ alloy foil at $400^{\circ} \mathrm{C}$. 


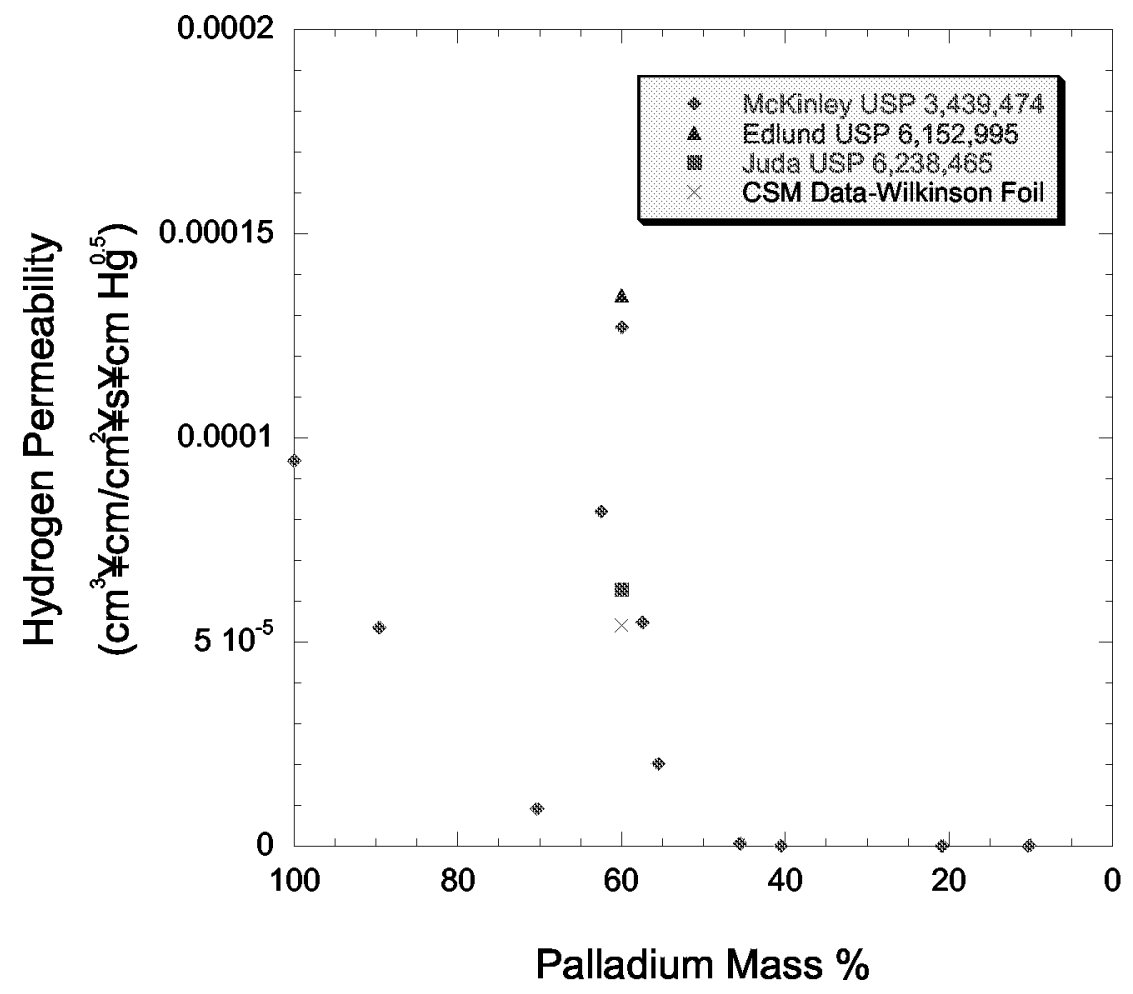

Figure 3. $\mathrm{H}_{2}$ permeability of $\mathrm{Pd}_{60} \mathrm{Cu}_{40}$ foils in the patent literature at $400^{\circ} \mathrm{C}$.

\subsection{Problems Encountered}

With respect to the issue of defects (pinholes) in the membranes, as indicated in the report last quarter, we have implemented parallel development paths to resolve the issue; namely,

- Functionalization of polymer surface as per proposed plan

- Post processing of films (i.e., $\mathrm{H}_{2}$ annealing/inert sealing material)

- Formation of "poorly adherent" films on atomically smooth, rigid surfaces (as per semiconductor industry practice)

- Use of alternative flexible sacrificial foils, such as aluminum, with incorporated etch stop layers

We have also encountered a problem relating to film damage by the o-ring in the Millipore test cell. As shown in Figure 4, the force exerted on the film by the Viton o-ring pushes the thin metal film into the large pores of the Monel screen support to create a huge leak path. In addition to substituting alternative porous structures for support (i.e., ceramic and stainless steel sponge materials) as one approach to overcome the problem, we are also considering swaging a thin foil, and/or re-flowing a braze alloy, such as $\mathrm{Au}-\mathrm{Si}$, into the pores of the Monel screen and in order to provide a smooth sealing surface. 


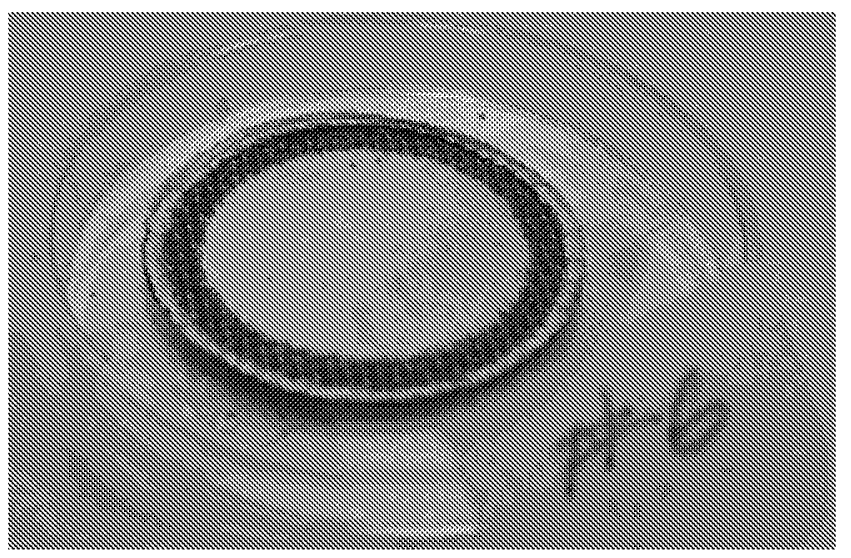

Figure 4. Damage to Cu film caused by pressure from o-ring seal.

\subsection{Plans for Next Reporting Period}

- Permeation testing with $25 \mathrm{~cm} 2,1-5 \mathrm{~mm}$-thick, Pd-Cu alloy membranes formed on silicon substrates,

- Optimization of $\mathrm{Pd}-\mathrm{Cu}$ alloy film formation in web coater system (sputtering and e-beam evaporation processes),

- Development of methods and procurement of porous support substrates to eliminate damage to membrane films.

\subsection{CONCLUSION}

As per the statement of work, we continued developing processing procedures for the formation of 1 - 5 mm-thick, Pd-Cu alloy films on PVA and PS backing materials. Pd-Cu alloy films, up to $25 \mathrm{~cm}$ widths have been produced although due to non-optimal functionalization (pre-treatment) of the polymer surface, films are either not contiguous and fall apart during the backing removal process or contain some level of defects. In addition to identifying alternative processing conditions to improve film properties, alternative film fabrication approaches have been identified, such as direct deposition onto silicon wafers with poor adhesion characteristics.

In the $\mathrm{H}_{2}$ permeation testing of a $25 \mu \mathrm{m}$-thick, $\mathrm{Pd}_{60} \mathrm{Cu}_{40}$ alloy foil, the permeability was determined to be $3.4 \times 10^{-5} \mathrm{~cm}^{3} \mathrm{cmcm}^{-2} \mathrm{~s}^{-1} \mathrm{cmHg}^{-1 / 2}$ (In agreement with results from others); permeation rates should increase proportionately to the decrease in membrane thickness and therefore, we should expect a 10-fold increase in permeation as the film thickness is decreased from $25 \mu \mathrm{m}$ to $<3 \mu \mathrm{m}$ as part of this effort.

\subsection{REFERENCES}

